\title{
Pengaruh Panjang Elektroda terhadap Pemisahan dan Kualitas Sperma X dan Y pada Domba
}

\author{
Effect of Electrode Length on the Separation and Quality of X and Y Sperm in Sheep \\ Y. S. Ondho, Sutiyono, E. Kurnianto, A. Suryawijaya, dan D. A. Lestari \\ Departemen Peternakan, Fakultas Peternakan dan Pertanian Universitas Diponegoro \\ Jalan Prof. H. Soedarto, S.H. Tembalang-Semarang \\ Corresponding Author: yon_supriondho@yahoo.com
}

\begin{abstract}
Objective of this study was to determine the results of $\mathrm{X}$ and $\mathrm{Y}$ sperm separation of the sheep from a variety of electrode length. The materials used were 6 ram which had minimum volume $0,4 \mathrm{ml}$ and motility $70 \%$ of semen. The latin squares design was used as research design with treatment : 7.0, 3.5 and $1.0 \mathrm{~cm}$ electrode length. Semen was collected using artificial vagina once a week and 3 times per head during the research. Semen collected was diluted, then was separated between X and Y sperm. Parameters observed were motility, viability, abnormality and sperm morphometric. Data were analyzed using descriptive statistics, t'student, regression and correlation. The results showed that the best and worst sperm quality were produced by $1.0 \mathrm{~cm}$ and $7.0 \mathrm{~cm}$ electrode length, respectively. The sperm quality had significant $(\mathrm{P}<0.05)$ relationship and significant $(\mathrm{P}<0.05)$ closeness relationship to the length of electrode. While the results of separation of sperm X and Y were not significantly different on the three treatments, and the length of electrode did not show any significant relationship with the result separation of sperm. In conclusion, the length of the electrodes did not affect the percentage of sperm $\mathrm{X}$ and $\mathrm{Y}$ of separation.
\end{abstract}

Key words: sheep, sperm, electrode, sexing, sperm quality.

\begin{abstract}
ABSTRAK
Penelitian bertujuan untuk mengetahui hasil pemisahan sperma X dan Y pada semen domba dari berbagai panjang elektroda. Materi yang digunakan yaitu 6 ekor domba jantan yang mempunyai semen dengan minimal volume $0,4 \mathrm{ml}$ dan motilitas $70 \%$. Penelitian menggunakan rancangan percobaan bujur sangkar latin dengan perlakuan panjang elektroda 1,$0 ; 3,5$ dan 7,0 cm. Penampungan semen dilakukan menggunakan vagina buatan setiap minggu sekali dan sebanyak 3 kali per ekor selama penelitian. Setiap semen hasil penampungan diencerkan, kemudian dilakukan pemisahan antara sperma X dan Y. Parameter yang diamati adalah motilitas, daya hidup, abnormalitas, morfometri sperma. Data dianalisis menggunakan statistik diskriptif, uji t'student, regresi dan korelasi. Hasil penelitian menunjukkan bahwa kualitas sperma yang terbaik dan terburuk masingmasing dihasilkan panjang elektroda $1 \mathrm{~cm}$ dan $7 \mathrm{~cm}$, kualitas sperma mempunyai hubungan yang nyata $(\mathrm{P}<0,05)$ dan keeratan hubungan yang nyata $(\mathrm{P}<0,05)$ terhadap panjang elektroda. Sedangkan hasil pemisahan sperma $\mathrm{X}$ dan Y tidak berbeda nyata pada ketiga perlakuan, dan panjang elektroda tidak menunjukkan ada hubungan yang nyata dengan hasil pemisahan sperma. Kesimpulan, panjang elektroda tidak berpengaruh terhadap persentase sperma X dan Y dari hasil pemisahan.
\end{abstract}

Kata kunci: domba, sperma, elektroda, sexing, kualitas sperma.

\section{PENDAHULUAN}

Ternak pedaging merupakan ternak yang hanya sekali menghasilkan daging selama hidupnya, karena setelah diambil dagingnya (dipotong) ternak tersebut sudah tidak ada (mati). Oleh sebab itu untuk menghasilkan daging ruminnsia yang berkesinambungan, perlu dicari jalan untuk menghasilkan ternak ruminansia yang mempunyai produktivitas daging tinggi, untuk mendungkung tercapainya swasembada daging ternak ruminansia serta mempertahankannya setelah tercapai. Usaha mendapatkan ternak pedaging yang pertumbuhannya cepat dan proses perkembanganbiakannya tidak terganggu perlu dilakukan dengan program menghasilkan anak jantan lebih banyak dari pada anak betina. Anak jantan dapat dijadikan sebagai bakalan untuk digemukan sebagai penghasil daging, sedang anak betina digunakan untuk memperbanyak jumlah 
induk atau sebagai penganti induk yang sudah tua.

Domba merupakan salah satu ternak yang ikut mendukung pemenuhan kebutuhan daging ruminansia Nasional dapat dijadikan sebagai model dalam penelitian. Potensi domba berdasarkan data Kementerian Pertanian (2015) produksi dagingnya dari tahun 2011 sampai 2015 terus menurun. Berdasarkan tren penurunan tahun 20112015 tersebut produksi prediksi daging domba tinggal kurang lebih 2000 ton pada tahun 2025. Penurunan produksi daging domba tersebut dapat disebabkan karena kelahiran anak domba rendah dan domba betina banyak yang dipotong untuk memenuhi kebutuhan daging domba. Pemecahan permasalahan penurunan daging domba tersebut dapat dilakukan dengan cara menghasilkan anak domba jantan yang lebih banyak dari domba betina sehingga mengurangi/mencegah pemotongan domba betina produktif.

Domba jantan mempunyai pertumbuhan yang lebih cepat dan mempunyai postur tubuh yang lebih besar, sehingga dapat menghasilkan daging yang lebih banyak dari pada domba betina. Meningkatnya jumlah domba jantan yang dihasilkan dapat memperbanyak produksi daging, dan akan mengurangi jumlah induk domba produktif yang dipotong. Program menghasilkan domba jantan yang lebih banyak merupakan salah satu jalan untuk membantu kecukupan kebutuhan daging domba di Indonesia. Suatu usaha untuk mendapatkan jumlah anak jantan lebih banyak adalah dengan cara mengembangkan dan menerapkan teknologi pemisahan sperma $\mathrm{X}$ dan $\mathrm{Y}$ yang terpadu dengan program Inseminasi Buatan (IB) pada domba.

Dasar Pemisahan sperma menurut Hafez (1993), spermatozoa Y mempunyai morfologi lebih kecil dan lebih ringan dari pada spermatozoa $X$. Spermatozoa yang mempunyai gonosom $\mathrm{Y}$ geraknya lebih cepat dari pada spermatozoa bergonosom X. Spermatozoa Y mempunyai kandungan DNA kurang lebih 4\% lebih sedikit daripada DNA spermatozoa X (Hafez. 1993). Perbedaan kandungan DNA spema $\mathrm{X}$ tersebut lebih besar dari 3,8 \% dari sperma Y (Moore dan Thatcher, 2006 dan Tubman et al., 2004). Spermatozoa bergonosom $\mathrm{X}$ mempunyai muatan listik negatif sehingga mempunyai kecenderungan ditarik oleh listrik muatan positif, sedang spermatozoa bergonosom Y mempunyai muatan listrik positif sehingga mempunyai kecenderungan ditarik listrik muatan negatif (Garner dan Hafez, 1993).

Banyak metode pemisahan sperma $X$ dan $Y$ yang hasilnya tidak memuaskan karena faktor zat-zat yang digunakan dan lama waktu pemisahan yang menyebabkan kualitas spemanya rendah. Pemisahan sperma $\mathrm{X}$ dan $\mathrm{Y}$ yang berbasis pada setiap sel spermatozoa, menghasilkan pemisahan sperma yang sangat baik. Pemisahan sperma $\mathrm{X}$ dan $\mathrm{Y}$ menggunakan metode "Flow Cytometry/ceel" merupakan pemisahan yang berbasis pada setiap sel spermatozoa, hasilnya sangat baik dalam menghasilkan jenis kelamin anak sapi dengan ketepatan mencapai 90\% (Hough dan Foote, 2002 dan Tubman et al., 2004). Namun, metode tersebut memiliki keterbatasan yaitu dapat menyebabkan kerusakan sperma (Sharma and Sharna, 2016). Kerusakan strutural sperma setelah pemisahah sangat berhubungan dengan fungsional kelayakan sperma digunanakan untuk Inseminasi Buatan (IB) dan menjadi faktor utama dalam evaluasi (Carvalho et al., 2014). Faktor stres sperma saat pemisahan sangat berpengaruh terhadap mitokondria, sehingga mengurangi masa hidup spermatozoa (Rath et al., 2013).

Inseminasi buatan menggunakan semen hasil pemisahan sperma metode "Flow Cytometry/cell" menghasilkan kebutingan berkisar $43-68 \%$ pada sapi, tetapi tidak dapat mengetahui jenis kelamin anak yang dihasilkan, sebab sapi yang di IB pada akhirnya banyak yang dijual oleh peternak sehingga sulit untuk dilakukan pemantauan jenis kelamin anak yang dihasilkan (Garner dan Siedel, 2000). Selanjutnya Garner dan Siedel (2000) menyatakan bahwa banyak terjadi kematian dan keguguran embrio pada kandungan umur satu dan dua bulan setelah induk di IB, yang diduga akibat dari kualitas 
spermatozoa hasil pemisahan yang lemah, dan setelah dilakukan pengulangan percobaan tetap menunjukkan hasil yang sama. Kendala dari metode Flow Cytometry adalah waktu pemisahan yang lama yang menyebabkan adanya antigen pada membran sperma sehingga menyebabkan keberhasilan IB yang rendah (Malik et al., 2011). Sejauh ini, belum ditemukan metode yang tepat untuk permisahan sperma $\mathrm{X}$ dan $\mathrm{Y}$, yang diharapkan dapat menghasilkan jenis kelamin anak yang dilahirkan sesuai dengan yang diinginkan oleh breeder (Pindaru et al., 2016).

Teknologi pemisahan spermatozoa $\mathrm{X}$ dan $\mathrm{Y}$ dengan metode elektrik merupakan metode yang membutuhkan waktu yang relatif singkat dan dapat menggunakan zat kimia sebagai pengencer semen yang tidak memberikan pengaruh negatif terhadap kualitas spermatozoa serta layak digunakan untuk IB. Hingga saat ini proses pemisahan sperma menggunakan metode elektrik belum banyak berkembang, maka dalam pemisahan sperma $\mathrm{X}$ dan $\mathrm{Y}$ pada ternak potong perlu diteliti panjang elektroda yang mampu menghasilkan sperma yang mempunyai fertilitas tinggi 70-90\% dengan harapan perbandingan antara sperma $\mathrm{X}$ dengan $\mathrm{Y}$ hasil pemisahan adalah sebanyak 20-10\% dengan 80-90 \%. Perbandingan sperma $X$ dengan $\mathrm{Y}$ tersebut masih dapat menghasilkan anak betina yang mencukupi untuk penganti (replacemen stock) dan menambah jumlah induk domba, sedangkan anak domba jantan bisa dihasilkan lebih banyak untuk digemukan sebagai penghasil daging, sehingga perkembangbiakan domba tetap berjalan dengan baik, kontinyuitas produksi daging domba tetap terjaga, bahkan dapat meningkat setiap tahun untuk mencukupi kebutuhan pasar. Oleh karena itu, tujuan dari penelitian ini adalah untuk mengetahui hasil pemisahan sperma $\mathrm{X}$ dan $\mathrm{Y}$ pada domba dari berbagai panjang elektroda.

\section{MATERI DAN MATODE}

Penelitian dilakukan di Laboratorium Genetika, Pemuliaan dan Reproduksi
Fakultas Peternakan dan Pertanian Universitas Diponegoro. Materi penelitian 6 ekor domba jantan dewasa yang menghasilkan sperma berkualitas baik yaitu volume berkisar $0,4-0,7 \mathrm{ml}$ dengan motilitas $70-90 \%$.

Domba dipelihara dalam kandang individu dan diberi pakan berupa rumput lapangan sebanyak $5 \mathrm{~kg}$ berat kering dan $1 \mathrm{~kg}$ bekatul perekor/hari. Semen hasil dari setiap penampungan diencerkan 20 kali menggunakan aquabides sehingga konsentasi $10 \times 10^{6} / \mathrm{ml}$, kemudian dilakukan pemisahan dengan aliran listrik yang mempunyai tegangan $3 \mathrm{~V}$ dan arus listik 1A. Pemisahan menggunakan 3 macam panjang elektroda sebagai perlakuan yaitu:

a. $\mathrm{T}_{1}$ : panjang elektroda $1 \mathrm{~cm}$.

b. $\mathrm{T}_{2}$ : panjang elektroda $3,5 \mathrm{~cm}$

c. $\mathrm{T}_{3}$ : panjang elektroda $7 \mathrm{~cm}$.

Semen dari setiap hasil pemisahan dibuat tiga preparat ulas sperma. Setiap preparat ulas diamati menggunakan Microsphot FXA Nikon Photomicrographic Applications, kemudian bagian preparat apus yang mempunyai sperma yang tersebar (tidak banyak yang berhimpitan) difoto 3 bagian dengan perbesaran 1000x. Sisa semen yang dibuat preparat ulas ditambah 2 bagian pengencer (aquabides yang mengandung kuning telur $4 \%$ ).

Perameter yang diamati :

a. Motilitias sperma (\%): sperma yang bergerak maju pada semen hasil pemisahan yang mengandung kelompok sperma Y atau tertarik listrik negatif.

b. Daya hidup sperma setelah 10 menit (\%): sperma yang bergerak maju pada semen hasil pemisahan yang mengandung kelompok sperma $\mathrm{Y}$ atau tertarik listrik negatif, setelah disimpan selama 10 menit dalam ruang.

c. Abnormalias sperma (\%): banyaknya sperma abnormal pada semen hasil pemisahan yang mengandung kelompok sperma Y atau tertarik listrik negatif. 
d. Ukuran sperma: ukuran bagian spermatozoa dalam posisi kepala tampak bulat atau oval (tidak gepeng). Pengukuran bagian spermazoa menggunakan metode Coreldraw X3 vesion 13 lisensi no 2005, pada sperma yang ditarik oleh elektroda positif dan elektroda negatif. Rata-rata ukuran spema dari kelompok sperma yang ditarik oleh elektroda positif dan elektroda negatif merupakan batas ukuran untuk menentukan sperma $\mathrm{X}$ dan Y. Ukuran spermatozoa tersebut meliputi:

- Panjang kepala, diukur pada bagian kepala spermatozoa yang terpanjang (micron). Sperma yang ditarik elektroda negatif dan yang mempunyai ukuran panjang kepala dibawah ratarata dari ukuran panjang kepala sperma, dinyatakan sebagai sperma Y.

- Lebar kepala diukur pada bagian kepala spermatozoa yang terlebar (micron). Sperma yang ditarik elektroda negatif dan yang mempunyai ukuran lebar kepala dibawah rata-rata dari ukuran lebar kepala sperma dinyatakan sebagai sperma Y.

- $\quad$ Panjang ekor diukur dari pangkal ekor yang berbatasan dengan kepala sampai ujung ekor (micron). Sperma yang ditarik elektroda negatif dan yang mempunyai ukuran ekor lebih panjang dari rata-rata ukuran ekor sperma, dinyatakan sebagai sperma $Y$.

\section{Analisis Data}

Data sperma yang ditarik elektroda negatif berdasarkan ukuran panjang kepala, lebar kepala dan panjang ekor, dianalisis secara statistik diskriptif dengan cara membandingkan presentasenya. Data kualitas dan ukuran sperma, dianalisis menggunakan uji t'student dilakukan sampai perbedaan yang nyata $(\mathrm{P}<0,05)$, dan regresi dan korelasi sederhana menurut prosedur Steel and Torrie (1989) dengan bantuan program SPSS versi 6.

\section{HASIL DAN PEMBAHASAN}

Motilitas, daya hidup dan abnormalitas sperma merupakan faktorfaktor yang berpengeruh terhadap keberhasilan pembuahan atau fertilisasi sel telur. Hasil pemisahan sperma domba menggunakan metode pengaliran semen pada elektroda yang mempunyai panjang 7,$0 ; 3,5$ dan $1 \mathrm{~cm}$ yang ditarik oleh listrik negatif (sperma Y) disajikan pada Tabel 1, dan hubungan antara panjang elektroda dengan motilitas, daya hidup dan abnormalitas sperma hasil pemisahan disajikan pada Tabel 2.

Tabel 1 menunjukkan bahwa hasil analisis statistik motilitas sperma antara perlakuan $T_{1}$ dengan $T_{2}$ tidak berbeda nyata, tetapi keduanya mempunyai motilitas yang lebih baik dan berbeda nyata $(\mathrm{P}<0,05)$ dengan $\mathrm{T}_{3}$ yang mempunyai motilitas terendah. Daya hidup sperma pada pemisahan $T_{1}$ yang tidak berbeda dengan $T_{2}$, tetapi berbeda nyata $(\mathrm{P}<0,05)$ dengan $\mathrm{T}_{3}$, yang mempunyai daya hidup tidak berbeda nyata dengan $\mathrm{T}_{2}$. Analisis abnormalitas pada $\mathrm{T}_{1}$ menunjukkan hasil yang terbaik dan berbeda nyata $(\mathrm{P}<0,05)$ dengan $\mathrm{T}_{2}$, dan sangat berbeda nyata $(\mathrm{P}<0,05)$ dengan $\mathrm{T}_{3}$ yang mempunyai abnormalitas terburuk.

Tabel 1. Pengaruh panjang elektroda terhadap rata-rata motilitas, viabilitas dan abnormalitas sperma domba

\begin{tabular}{lccc}
\hline \multirow{2}{*}{ Parameter } & \multicolumn{3}{c}{ Perlakuan } \\
\cline { 2 - 4 } & $\mathrm{T} 1$ & $\mathrm{~T} 2$ & $\mathrm{~T} 3$ \\
\hline Motilitas (\%) & $83,04^{\mathrm{a}}$ & $70,53^{\mathrm{a}}$ & $50,89^{\mathrm{b}}$ \\
Daya hidup (\%) & $69,72^{\mathrm{a}}$ & $57,26^{\mathrm{ab}}$ & $41,47^{\mathrm{b}}$ \\
Abnormalitas (\%) & $18,29^{\mathrm{a}}$ & $27,44^{\mathrm{b}}$ & $43,54^{\mathrm{c}}$ \\
\hline
\end{tabular}

Superskrip yang berbeda pada baris yang sama menunjukkan perbedaan yang nyata $(\mathrm{P}<0,05)$ 
Kualitas sperma hasil pemisahan pada $\mathrm{T}_{1}$ merupakan kualitas yang terbaik, karena mempunyai rata-rata motilitas $83,04 \%$, daya hidup $69,72 \%$ dan abnormalitas $18,29 \%$ yang layak digunakan untuk IB. Sperma yang layak digunakan untuk IB mempunyai motilitas minimal 40\% (Toelihere, 1985) dan mempunyai abnormalitas maksimal 20\% (Partodihardjo, 1987). Faktor daya hidup sperma setelah 10 menit disuhu ruang sebesar 69,72\%, menunjukkan bahwa kesempatan untuk melaksanakan IB mempunyai waktu yang lebih dari 10 menit. Motilitas, ukuran dan bentuk sperma berhubungan dengan transportasi sperma dan seleksi di dalam saluran reproduksi betina dari tempat diposisi sperma sampai tempat fertilisasi dan kemampuan membuahi ovum (Vázquez, et al., 2016).

Kualitas sperma hasil pemisahan pada $\mathrm{T}_{2}$ dan $\mathrm{T}_{3}$ tidak layak digunakan untuk IB karena faktor abnormalitas yang tinggi, yaitu masing-masing $27,44 \%$ dan 43,54\%. Motilitas, daya hidup dan abnormalitas sperma sangat berhubungan erat dengan panjang elektroda pada $T_{1}, T_{2}$, dan $T_{3}$. Tabel 1 menunjukkan bahwa motilitas sperma terbaik pada $T_{1}$ dan yang terburuk pada $T_{3}$ yang didukung oleh hasil yang tertera pada Tabel 2 yang menunjukkan adanya hubungan negatif yang nyata $(\mathrm{P}<0,05)$ antara panjang elektrodadengan motilitas sperma, dan keeratan hubungan negatif yang nyata $(\mathrm{P}<0,05)$ dengan koefisien korelasi ( $\mathrm{r}$ ) $0,999 \%$. Hubungan antara daya hidup sperma dengan panjang elektroda mempunyai hubungan yang negatif nyata $(\mathrm{P}<0,05)$ dan koefisien korelasi negatif nyata $(\mathrm{P}<0,05) \mathrm{r}=$ 0,999 sehingga daya hidup yang terbaik (terbesar) pada $\mathrm{T}_{1}$ yaitu $69,72 \%$. Hubungan antara abnormalitas sperma dengan panjang elektroda mempunyai hubungan yang positif nyata $(\mathrm{P}<0,05)$ dengan keeratan hubungan positif nyata $(\mathrm{P}<0,05)$ dengan koefisien korelasi (r) $+0,998$, sehingga abnormalitas sperma terbaik yang terkecil yaitu $18,29 \%$ pada $\mathrm{T}_{1}$.

Faktor yang terpenting dalam pemisahan sperma $\mathrm{X}$ dan $\mathrm{Y}$ adalah persentase sperma $\mathrm{Y}$ atau yang tertarik oleh listrik negatif untuk meningkatkan anak domba jantan yang dihasilkan pada program inseminasi. Hasil pemisahan sperma Y domba menggunakan metode pengaliran semen pada elektroda yang mempunyai panjang 1,$0 ; 3,5$ dan $7,0 \mathrm{~cm}$ disajikan pada Tabel 3, dan hubungan antara panjang elektroda dengan persentase sperma $\mathrm{Y}$ disajikan pada Tabel 4.

Tabel 3 menunjukkan bahwa hasil analisis statistik rata-rata persentase sperma yang ditarik listrik bermuatan negatif antar perlakuan pada parameter panjang kepala, lebar kepala dan panjang ekor tidak berbeda. Sedangkan hubungan antara panjang elektroda dengan persentase sperma $Y$ berdasarkan panjang kepala, lebar kepala dan panjang ekor, ketiganya menunjukkan persamaam regresi atau hubungan yang tidak nyata (Tabel 4).

Tabel 2. Hubungan antara panjang elektroda dengan motilitas, daya hidup dan abnormalitas sperma domba

\begin{tabular}{lcc}
\hline \multicolumn{1}{c}{ Parameter } & Persamaan regresi & Koefisien korelasi \\
\hline Motilitas & $\mathrm{Y}=88,76-5,37 \mathrm{X}^{*}$ & $-0,997^{*}$ \\
Daya hidup & $\mathrm{Y}=74,15-4,69 \mathrm{X}^{*}$ & $-0,882^{*}$ \\
Abnormalitas & $\mathrm{Y}=17,92+3,48 \mathrm{X}^{*}$ & $+0,817^{*}$ \\
\hline
\end{tabular}

Keterangan: Superskrip pada persamaan regresi menunjukkan adanya hubungan yang nyata $(\mathrm{P}<0,05)$ dan superskrip pada koefisien korelasi menunjukkan keeratan hubungan yang nyata $(\mathrm{P}<0,05)$. 
Tabel 3. Pengaruh panjang elektroda terhadap rata-rata panjang kepala, lebar kepala dan panjang ekor sperma domba

\begin{tabular}{lccc}
\hline \multirow{2}{*}{ Parameter } & \multicolumn{3}{c}{ Perlakuan } \\
\cline { 2 - 4 } & T1 & T2 & T3 \\
\hline Panjang kepala (\%) & 54,13 & 56,42 & 61,07 \\
Lebar kepala (\%) & 56,02 & 57,26 & 59,32 \\
Panjang ekor (\%) & 56,04 & 56,12 & 61,06 \\
\hline
\end{tabular}

Disamping itu, keeratan hubungan juga tidak nyata dengan koefisien korelasi ( $\mathrm{r}$ ) yang berkisar 0,014-0,029. Pemisahan yang mengasilkan persentase sperma $\mathrm{Y}$ berkisar 54,04-61,07\% berarti panjang elektroda 1; 3,5 dan $7 \mathrm{~cm}$ belum dapat memberikan hasil pemisahan sperma baik untuk memperoleh anak domba jantan yang lebih banyak. Faktor yang mempengaruhi persentase pemisah sperma $Y$ yang tidak nyata tersebut kemungkinan karena waktu pemisahan yang singkat yang hanya berkisar 7-9 menit. Faktor lama pemisahan sperma tesebut kemungkinan masih dapat memperbaiki $\mathrm{T}_{1}$, yang menghasilkan motilitas yang tinggi yaitu sebesar $83,04 \%$ dan abormalitas yang rendah sebesar $18,29 \%$, sedangkan pada T2 dan T3 sudah tidak mungkin dilakukan, karena persentase abnormalitas yang tinggi, masing-masing sebesar $27,44 \%$ dan $43,54 \%$ yang tidak layak untuk inseminasisi.

Hingga saat ini belum ditemukan metode permisahan sperma $\mathrm{X}$ dan $\mathrm{Y}$ yang tepat yang dapat memberikan hasil kualitas sperma sexing yang menjanjikan untuk kebuntingan (Pindaru et al., 2016). Evaluasi sperma non sexing dan sexing menggunakan metode flow cytometry menghasilkan persentase motilitas $(58,1 \pm 4,3$ dan $35,2 \pm 4,4)$, motilitas progresif $(46,1 \pm 6,1$ dan $25,7 \pm 4,8)$, potensial membran mitokondria $(79, \overline{2} \pm 8,3$ dan $69,0 \pm 6,3)$, stabilitas membran plasma $(77,4 \pm 4,6$ dan $19,4 \pm 4,2)$ dan hidup sperma dengan akrosom utuh $(57,2 \pm 8,5$ dan $31,3 \pm 7,9)$ lebih tinggi pada sperma non sexing dari pada sexing (Carvalho et al., 2018). Embrio yang dihasilkan secara in vitro dan in vivo dari penggunaan sperma sexing yang diamati pada 24 dan 48 jam tidak berbeda nyata (24 jam : $74,6 \%$ vs $75,5 \% ; 48$ jam: $64,5 \%$ vs $68,1 \%$ ), sedangkan dari sperma non sexing yang diamati pada 48 jam adalah $63,55 \%$ dan $55,5 \%$ (Trigal et al., 2012). Sapi perah yang disuperovulasi dan di IB menggunakan sperma non sexing menghasilkan persentase embrio lebih banyak dan ovum yang tidak dibuahi lebih sedikit dari pada yang di IB dengan sperma sexing (Monteiro et al., 2016).

Tabel 4. Hubungan antara panjang elektroda dengan ukuran sperma

\begin{tabular}{lcc}
\hline \multicolumn{1}{c}{ Ukuran sperma } & Persamaan regresi & Koefisien korelasi \\
\hline Panjang kepala & $\mathrm{Y}=52,73+1,17 \mathrm{X}$ & $+0,023$ \\
Lebar kepala & $\mathrm{Y}=56,49+0,05 \mathrm{X}$ & $+0,014$ \\
Panjang ekor & $\mathrm{Y}=60,37+0,03 \mathrm{X}$ & $+0,029$ \\
\hline
\end{tabular}

\section{KESIMPULAN}

Berdasarkan hasil dan pembahasan penelitian disimpulkan bahwa panjang elektroda tidak berpengaruh terhadap presentase sperma $\mathrm{X}$ dan $\mathrm{Y}$ hasil pemisahan.

\section{SARAN}

Diperlukan penelitian lebih lanjut mengenai pemisahan sperma $\mathrm{X}$ dan $\mathrm{Y}$ dengan panjang elektroda $1 \mathrm{~cm}$ yang diikuti modifikasi tegangan dan arus listrik yang lebih rendah. 


\section{DAFTAR PUSTAKA}

Carvalhoa, J.O., R. Sartoria and M.A.N. Dodec. 2014. Different ways to evaluate bovine sexed sperm in vitro. Anim. Reprod.11(3):199-206.

Carvalhoa, J.O., R. Sartoria, L. Rodellob, G.B. Mourãoa, S.D. Bicudob and M.A.N. Dodec. 2018. Flow cytometry sex sorting affects bull sperm longevity and compromises their capacity to bind to oviductal cells. Livestock Sci. 207: 30-37.

Garner, D.L. and E.S.E. Hafez. 1993. Spermatozoa and Seminal Plasma. In : E.S.E. Hafez (editor) Reproduction in Farm Animals. $6^{\text {th }}$ Ed. Lea \& Febiger, Philadelphia.

Garner, D.L and G.E. Seidel, Jr. 2000. Sexing Bull Sperm. In Tropics in Bull Fertility. Chenoweth, P.J (Ed). International Veterinary Information service Forf Collins, Colorodo.

Hafez, E.S.E. 1993. X and Y Chromosome Bearing Spermatozoa. In : E.S.E. Hafez (editor) Reproduction in Farm Animals. $6^{\text {th }}$ Ed. Lea \& Febiger, Philadelphia.

Hough, S.R. and R.H. Foote. 2002. Effect of density gradient osmolality on specific gravity of bull sperm and their separation, but not on basis of sex. J. Reprod and Develop. 48: 399-407.

Kemeterian Pertanian. 2015. Produksi Daging Domba Menurut Provinsi. Donwloadwww.pertanian.go.id/ap pages/mod/datanak. diakses 10 Maret 2017.

Malik, A., A.W.Haron, R. Yusoff, M. Bukar, A. Kasim and M. Sabri. 2011. Verification of $\mathrm{X}$ and $\mathrm{Y}$ spermatozoa separation by nested polymerase chain reaction (PCR), Motility and membrane integrity in bovine. Afric. J. Biotec. 10 (85): 19796-19801.

Monteiro, P.L.J. Jr., A.M. Batista, F.C. Almeida, A.E.S. Figueiredo, P.C. Soares, G.F. Carneiro and M.M.P. Guerra. 2016. Fertilization rate and embryo production of superovulated dairy cows after insemination with non-sorted and sex-sorted semen. Anim. Reprod., Belo Horizonte. 13 (2): 112-116.

Moore, K. and W.W. Thatcher. 2006. Major Advances Associated with Reproduction in Dairy Cattle. Department of Animal Sciences, University of Florida. J. Dairy Science. 89: 1254-1266.

Partodihardjo, S. $1987 . \quad$ Ilmu Reproduksi Hewan. Cetakan ke 2 Penerbit Mutiara Sumber Swadaya. Jakarta.

Pindaru, L., I.M. Balaci and I. S. Groza. 2016. Sperm sexing technology new directions in medicine Tehnologia sexării materialului seminal - o nouă direcție în medicină. Revista Română de Medicină de Laborator. 24 (1): 111121.

Rath, D., S. Barcikowski, S. de Graaf, W. Garrels, R. Grossfeld, S. Klein, W. Knabe, C' Knorr, W. Kues, H, Meyer, J. Michl, G. MoenchTegeder, C. Rehbock, U. Taylor and S. Washausen. 2013. Sex selection of sperm in farm animals: status report and developmental prospects. Reprod. 145: 15-30.

Sharma, M. and N. Sharma. 2016. Sperm Sexing in Animals; Review Article. Adv Anim. Vet. Sci. 4 (10): 543549.

Steel, R.G.D. dan J.H. Torrie. 1989. Prinsip dan Prosedur Satistika. Edisi Kedua. Alih Bahasa Bambang Sumantri. Penerbit: PT Gramedia, Jakarta. 
Toelihere, M. R. 1985. Inseminasi Buatan pada Ternak. Penerbit Angkasa, Bandung.

Trigal, B., E. Gómeza, J.N. Caamañoa, M. Muñoza, J. Morenob, S. Carroceraa, D. Martína and C. Dieza. 2012. In vitro and in vivo quality of bovine embryos in vitro produced with sexsorted sperm. Theriogenology 78: 1465-1475.
Tubman, L.M., Z. Brink, T.K. Suk and G.E. Seidel. Jr. 2004. Characteristics of Calves produced with sperm sexed by flow cytometry/cel sorting. J. Anim. Sci. 82: 1029-1036.

Vazquez, F.A.G., J. Gadeal, C. Matas and W.V. Holt. 2016. Importance of sperm morphology during sperm transport and fertilization in mammals. Asian J. Andrology. 18: $1-7$. 